University of Nebraska - Lincoln

DigitalCommons@University of Nebraska - Lincoln

6-6-2019

\title{
Does No-Tillage Mitigate Stover Removal in Irrigated Continuous Corn? A Multi-Location Assessment
}

\author{
Catherine E. Stewart \\ USDA-ARS, catherine.stewart@ars.usda.gov \\ Damaris L. Roosendaal \\ USDA-ARS \\ Aaron Sindelar \\ BAYER U.S. Crop Science \\ Elizabeth Pruessner \\ USDA-ARS \\ Virginia L. Jin \\ USDA-ARS, virginia.jin@ars.usda.gov \\ See next page for additional authors
}

Follow this and additional works at: https://digitalcommons.unl.edu/usdaarsfacpub

Stewart, Catherine E.; Roosendaal, Damaris L.; Sindelar, Aaron; Pruessner, Elizabeth; Jin, Virginia L.; and Schmer, Marty R., "Does No-Tillage Mitigate Stover Removal in Irrigated Continuous Corn? A MultiLocation Assessment" (2019). Publications from USDA-ARS / UNL Faculty. 2186.

https://digitalcommons.unl.edu/usdaarsfacpub/2186

This Article is brought to you for free and open access by the U.S. Department of Agriculture: Agricultural Research Service, Lincoln, Nebraska at DigitalCommons@University of Nebraska - Lincoln. It has been accepted for inclusion in Publications from USDA-ARS / UNL Faculty by an authorized administrator of DigitalCommons@University of Nebraska - Lincoln. 
Authors

Catherine E. Stewart, Damaris L. Roosendaal, Aaron Sindelar, Elizabeth Pruessner, Virginia L. Jin, and Marty R. Schmer

This article is available at DigitalCommons@University of Nebraska - Lincoln: https://digitalcommons.unl.edu/ usdaarsfacpub/2186 


\section{Does No-Tillage Mitigate Stover Removal in Irrigated Continuous Corn? A Multi-Location Assessment}

\section{Catherine E. Stewart* \\ Damaris L. Roosendaal \\ USDA-ARS \\ Soil Management and Sugar Beet \\ Research \\ 2150 Centre Avenue \\ Building D, Suite 100 \\ Fort Collins, CO 80526-8119}

Aaron Sindelar

BAYER U.S. Crop Science

$3820 \mathrm{~N}$ 56th St.

Lincoln, NE 68504

\section{Elizabeth Pruessner}

USDA-ARS

Soil Management and Sugar Beet

Research

2150 Centre Avenue

Building D, Suite 100

Fort Collins, CO 80526-8119

Virginia L. Jin

Marty R. Schmer

Agroecosystem Management Research Unit, USDA-ARS

251 Filley Hall

Univ. of Nebraska

Lincoln, NE 68583-0937

\section{Core Ideas}

- Long-term residue removal with irrigation may degrade soil despite no-tillage.

- Residue removal was assessed across three irrigated corn no-tillage sites.

- Stover removal decreased soil organic C stocks by $6 \%$ and soil aggregation by $12 \%$.

- Stover removal did not affect soil microbial biomass or composition.

- No tillage alone is not adequate to reduce erosion and maintain soil function.
No-tillage (NT) may ameliorate negative effects on soil properties from corn (Zea mays L.) stover harvest, but few long-term irrigated continuous corn production systems have been evaluated to test this hypothesis. We evaluated three long-term no-tillage sites (4-13 yr) in Nebraska and Colorado that spanned a range of precipitation and soil organic carbon (SOC) levels. We measured SOC, $\delta^{13} \mathrm{C}$ of SOC, soil microbial biomass (SMB) and composition (i.e., phospholipid fatty acids, PLFAs), and water stable aggregation at all sites under stover retention vs. removal $(\sim 60 \%)$. Surface SOC stocks $(0-30$ $\mathrm{cm}$ depth) increased across the gradient and were $46.4,57.4$, and $63.1 \mathrm{Mg}$ $\mathrm{C} \mathrm{ha}^{-1}$ for Colorado, central Nebraska, and eastern Nebraska, respectively. Overall, residue removal decreased SOC stocks by $6 \%$ and soil aggregation by $12 \%$ in the 0 - to $30-\mathrm{cm}$ depth. The $\delta^{13} \mathrm{C}$ signature of SOC indicated less new surface $C$ storage under residue removal in Colorado, but not at the two Nebraska sites. Residue harvest did not decrease SMB or change soil microbial community structure, suggesting that high plant productivity buffered community composition from stover harvest impacts under NT but stimulated microbial activity levels that led to SOC loss. The high rates of stover removal used in this study decreased SOC stocks and aggregation at all sites compared to residue retained treatments, suggesting that no-tillage alone was not sufficient to maintain erosion protection and soil function.

Abbreviations ARDEC, Agricultural Development and Education Center in Colorado; dbRDA, distance-based redundancy analysis; ENREC, eastern Nebraska Extension and Research Center; Harv, $>60 \%$ residu removal; NT, no-tillage; PLFA, phospholipid fatty acid; PLFA-C, phospholipid fatty-acid carbon; Ret, residue retained; SCAL, south central Agricultural Laboratory in Nebraska; SMB, soil microbial biomass; SOC, soil organic carbon.

$\mathrm{T}$ The return of crop residues such as corn stover to the soil is essential to agroecosystem functioning and maintaining soil $\mathrm{C}$ stocks, aggregation, and soil microbial communities. Harvesting corn stover, however, provides livestock feed, is anticipated to become a large-scale feedstock for cellulosic ethanol production, and removal can enhance early season plant growth (Sindelar et al., 2013). Developing sustainable harvest recommendations that protect the soil from erosion and SOC loss has been of considerable interest (Johnson et al., 2014; Wilhelm et al., 2007). Conservation management practices, such as NT, manure application (Blanco-Canqui et al., 2014), and cover crops (Osborne et al., 2014) may mitigate the negative environmental effects of stover removal by reducing soil disturbance and providing additional soil C input (Johnson et al., 2013; Sindelar et al., 2013). However, the effects of stover removal can be site- and treatment-specific (Osborne et al., 2014), such that the overall effect remains uncertain (Qin et al., 2016). Recent meta-analyses find conflicting effects of residue removal on SOC stocks, ranging from no consistent effect even with removal rates as high as 70\% (Qin et al., 2016) to overall SOC loss with removal rates of 25 to 100\% (Anderson-Teixeira et al., 2009).

Soil Sci. Soc. Am. J. 83:733-742

doi:10.2136/sssaj2018.09.0352

Received 27 Sept. 2018.

Accepted 13 Feb. 2019

*Corresponding author (catherine.stewart@ars.usda.gov).

(C) 2019 The Author(s). Re-use requires permission from the publisher. 
Table 1. Site characteristics for the three irrigated long-term residue removal studies sampled.

\begin{tabular}{|c|c|c|c|c|c|c|c|c|c|c|c|}
\hline Site & State & MATt & MAP & Soil series and type & $\begin{array}{c}\text { Bulk } \\
\text { density }\end{array}$ & pH & SOC & $\begin{array}{c}\text { Irrigation } \\
\text { amount }\end{array}$ & Removal rate & $\begin{array}{c}\text { Fertilizer } \\
\mathrm{N} \text { rate }\end{array}$ & $\begin{array}{c}\text { Study } \\
\text { duration }\end{array}$ \\
\hline & & ${ }^{\circ} \mathrm{C}$ & $\mathrm{mm}$ & & $\mathrm{g} \mathrm{cm}^{-3}$ & & $\mathrm{~g} \mathrm{~kg}^{-1}$ & $\mathrm{~mm}$ & $\%$ & $\mathrm{~kg} \mathrm{ha}^{-1}$ & $\mathrm{yr}$ \\
\hline ARDEC $\neq$ & Colorado & 10.6 & 383 & Fort Collins clay loam & 1.49 & 8.3 & 10.5 & $411 \pm 6$ & 66 & 202 & 9 \\
\hline SCAL§ & Nebraska & 10.3 & 731 & Hastings silt loam & 1.25 & 6.8 & 16.2 & 134.9 & 63 & 200 & 4 \\
\hline ENREC $\mid$ & Nebraska & 9.8 & 740 & Filbert, Tomek silt loams & 1.13 & 6.6 & 18.7 & $125 \pm 7$ & 70 & 202 & 13 \\
\hline
\end{tabular}

+ MAT, mean annual temperature; MAP, mean annual precipitation; SOC, soil organic carbon.

‡ ARDEC, Colorado. Data from Halvorson and Stewart (2015).

$\S$ SCAL, central Nebraska. Data from Blanco-Canqui et al. (2014).

- ENREC, eastern Nebraska. Data from Schmer et al. (2014).

A major challenge in determining overall stover removal effects include microsite factors that impact plant growth, rooting characteristics (Johnson et al., 2006), and soil water retention, all of which determine the direction and magnitude of SOC cycling (Hooker et al., 2005; Mann et al., 2002). Generally, NT stimulates surface rooting from increased water and nutrient availability due to residue cover (Qin et al., 2006). Long-term stover removal can reduce crop yields and root $\mathrm{C}$ inputs that subsequently reduce SOC storage (Halvorson and Stewart, 2015), soil aggregation (Jin et al., 2015; Osborne et al., 2014), and SMB (Stewart et al., 2014). However, other studies in rainfed NT corn systems in Nebraska, Minnesota, Canada, and other regions have not observed decreased SMB (Ahlschwede, 2013; Johnson et al., 2013; Spedding et al., 2004) or appreciable changes in microbial composition with residue removal (Lehman et al., 2014). Nitrogen fertilization has been shown to further impact stover removal effects, where limited crop C inputs due to low$\mathrm{N}$ fertilization exacerbates both soil $\mathrm{C}$ loss and reduces SMB with residue removal under irrigated continuous corn (Stewart et al., 2018). No changes in microbial community structure with residue removal suggest that NT with moderate residue removal rates may be an effective management practice that does not significantly compromise agroecosystem function.

Soil microbial biomass comprises a small portion of soil $\mathrm{C}$, yet it is critical to maintaining soil $\mathrm{C}$ cycling and soil function. Recent studies have found microbial processing to be the key transformation in efficient soil C stabilization (Cotrufo et al., 2015). Irrigation increases plant productivity and should enhance soil C storage (Lal et al., 1998), but many studies find that irrigated systems rapidly cycle soil C rather than store enhanced plant productivity in the form of SOC (Verma et al., 2005; Denef et al., 2008; Gillabel et al., 2007; Stewart et al., 2017). Microbial transformations are particularly important in irrigated production systems where stabilized $\mathrm{C}$ may be more susceptible to $\mathrm{C}$ losses through subsequent management changes (Stewart et al., 2018). Few studies span geographic gradients in precipitation and SOC to determine the generalizable effects of stover removal, particularly in irrigated systems.

Residue removal effects on C cycling in these irrigated systems will depend on the balance of plant productivity and microbial decomposition and are likely to be mediated by edaphic microsite effects as well as inherent SOC concentration and nutrient availability. We evaluated long-term residue removal effects on SOC stocks, $\delta^{13} \mathrm{C}$ of SOC, soil aggregation, and microbial biomass and composition (phospholipid fatty-acid carbon, PLFA-C) for three irrigated NT continuous corn sites spanning a SOC and precipitation gradient from western Colorado to eastern Nebraska. Our hypotheses were that: (i) long-term stover removal will decrease SOC stocks, soil aggregation, and the stabilization of new cornderived C even under NT management; and (ii) stover removal will reduce microbial biomass and shift the microbial community toward a more bacterial-dominated community.

\section{MATERIALS AND METHODS Experimental Sites and Treatments}

Three irrigated, NT continuous corn production systems in eastern Colorado, south central and eastern Nebraska (Table 1) were evaluated. All sites were managed with stover retention (Ret) or stover harvested (Harv; $>60 \%$ removal) with $\mathrm{N}$ fertilizer rates of $\sim 200 \mathrm{~kg} \mathrm{~N} \mathrm{ha}^{-1}$ representing typical producer practice.

\section{Site Descriptions}

Colorado. The study site is located near Fort Collins, CO, on the Agricultural Development and Education Center (ARDEC) $\left(40^{\circ} 39^{\prime} 6^{\prime \prime} \mathrm{N}, 104^{\circ} 59^{\prime} 57^{\prime \prime} \mathrm{W} ; 1535 \mathrm{~m}\right.$ above sea level). Mean annual precipitation is $38.3 \mathrm{~cm}$ and mean annual temperature is $10.6^{\circ} \mathrm{C}$ (Table 1). The soil is a Fort Collins clay loam soil (fine-loamy, mixed, mesic Aridic Haplustalf) with a 1 to 2\% slope. The study began in 2008 in an irrigated field that was NT since 2001, previously cropped to corn for two consecutive years prior to initiating the study. The full experimental design for this site is described in Halvorson and Stewart (2015). Briefly, it was a split-plot randomized complete block with three replications of three split-N rates and two residue treatments ( 0 or $66 \%$ removal). Fertilizer $\mathrm{N}$ rates were $0,67,202 \mathrm{~kg} \mathrm{~N} \mathrm{ha}^{-1}$. This study focuses only on the two residue treatments at the $202 \mathrm{~kg} \mathrm{~N} \mathrm{ha}^{-1}$ rate.

Corn was directly planted into the previous year's corn stover. Main plots ( $\mathrm{N}$ rate) were 10.7 by $21.3 \mathrm{~m}$ and subplots (residue treatment) were 5.4 by $21.3 \mathrm{~m}$. Triple superphosphate $(0-46-0)$ was applied to avoid corn P deficiency in $1999\left(56 \mathrm{~kg} \mathrm{P} \mathrm{ha}^{-1}\right), 2004$ (28 $\left.\mathrm{kg} \mathrm{P} \mathrm{ha}^{-1}\right), 2005$ (53 kg P ha $\left.{ }^{-1}\right), 2009$ (20 kg P ha-1), 2010 $\left(56 \mathrm{~kg} \mathrm{P} \mathrm{ha}^{-1}\right)$, and $2013\left(56 \mathrm{~kg} \mathrm{P} \mathrm{ha}^{-1}\right)$. A linear-move sprinkler irrigation system applied water as needed during the growing season, averaging $411 \mathrm{~mm}$ each year over the study duration. Fertilizer $\mathrm{N}$ was surface banded annually $\left(202 \mathrm{~kg} \mathrm{~N} \mathrm{ha}^{-1}\right)$ near the corn row at emergence in mid-May as polymer-coated urea (2008-2011) 
or nitrification/urease inhibitor urea (SuperU, 2012-2014). Herbicides were applied after planting and used as needed to control weeds for the duration of the study.

For the Harv treatment, stover from the previous corn crop was removed using a two-row forage harvester to chop and place the stover into an attached weigh wagon. Stover for the 2008 crop was removed in fall 2007, and in January 2009 for the 2009 crop. All subsequent removals occurred 2 to $4 \mathrm{wk}$ before planting instead of after grain harvest to minimize wind erosion over the fallow period. For the Ret treatment, all stover from the previous corn crop was retained with no field operations following combine harvest.

Central Nebraska. The study site is located at the University of Nebraska-Lincoln's South Central Agricultural Laboratory (SCAL) near Clay Center, NE, $\left(40.582^{\circ} \mathrm{N}, 98.144^{\circ} \mathrm{W} ; 552 \mathrm{~m}\right.$ above sea level). Long-term (1983-2014) mean annual temperature is $10.3^{\circ} \mathrm{C}$, and mean annual precipitation is $73 \mathrm{~cm}$, with $45 \mathrm{~cm}$ occurring during the growing season (April-October). Soils are classified as Hastings silt loam (fine, smectitic, mesic Udic Argiustoll) with $<3 \%$ slope. The site was established in 2010 following ridge-tilled soybean. The field encompassed an area of 5 ha managed under NT continuous corn with a variable rate linear-move irrigation system. The full experimental design for this site is described in Blanco-Canqui et al. (2014). Briefly, the experimental design is a randomized split-split-split block with four replications of irrigation treatments split into amendment treatments split into residue treatments with two levels of $\mathrm{N}$ fertilizer.

Main plots (irrigation) were 24 by $155 \mathrm{~m}$ for each level, where full irrigation maintained between 45 and $90 \%$ of the available water holding capacity to a depth of $1.2 \mathrm{~m}$ while the deficit irrigation treatment was $60 \%$ of fully irrigated treatments. Each irrigation-level plot was split into 24 by $52 \mathrm{~m}$ stover amelioration plots and treated with animal manure, winter rye (Secale cereale L.) crop, or non-ameliorated control. Each amelioration plot was then split again into 12 by $52 \mathrm{~m}$ stover management plots where stover was either harvested or retained. Finally, stover management plots were further divided into two 12 by 26 $\mathrm{m} \mathrm{N}$ fertilizer plots, receiving either 125 or $200 \mathrm{~kg} \mathrm{~N} \mathrm{ha}^{-1}$ as urea ammonium nitrate post-emergence. Here, we report residue retention and harvest data only from the fully irrigated, nonameliorated control plots under $200 \mathrm{~kg} \mathrm{~N} \mathrm{ha}^{-1}$.

For the stover removal treatment (Harv), stover was harvested in late October following grain harvest using a flail shredder, highcapacity hay rake, and round baler in 2010 and 2011, and with a self-propelled disk mower-conditioner and round baler in 2012 to 2014. Mean harvest rate was $6.5 \mathrm{dry} \mathrm{Mg} \mathrm{ha}^{-1} \mathrm{yr}^{-1}$, or $63 \%$ of total non-grain aboveground biomass over the course of the study.

Eastern Nebraska. The study site is located near Ithaca, NE, at the University of Nebraska-Lincoln's Eastern Nebraska Extension and Research Center (ENREC) (41 ${ }^{\circ}{ }^{\prime} 43.3^{\prime \prime}$ N, 96²4'41.4” W; $349 \mathrm{~m}$ above sea level). Long-term (1981-2010) mean annual precipitation is $74 \mathrm{~cm}$ and temperature is $9.8^{\circ} \mathrm{C}$. Soils are classified as Filbert silt loam (fine, smectitic, mesic Vertic Argialboll) and Tomek silt loam (fine, smectitic, mesic Pachic Argiudoll). The site was established in 2000, and the full experimental design for this site is described in Schmer et al. (2014) and Jin et al. (2017). Briefly, the experimental design is a randomized complete block with factorial treatment arranged in split plots with six replications of tillage treatment split into residue treatments.

Main plots (tillage) were 9 by $45.6 \mathrm{~m}$ per treatment, either NT or conventional disk tillage. Subplot (residue removal) treatments were initiated in 2001. Subplots within the main plots were arranged in 9 by $15.2 \mathrm{~m}$ blocks and split by stover removal rate: none $(0 \%)$, moderate $(\sim 35 \%)$, and high ( $70 \%)$. Nitrogen fertilizer was applied at $202 \mathrm{~kg} \mathrm{~N} \mathrm{ha}^{-1}$ for the last $7 \mathrm{yr}$ of the study. A solid set sprinkler system was used for irrigation in 2001 and 2002, after which (2003-2014) supplemental water was applied when necessary using a linear-move irrigation system. Here, we report residue retention and harvest data only from the high removal rate plots under $202 \mathrm{~kg} \mathrm{~N} \mathrm{ha}^{-1}$.

For the stover removal treatment (Harv), stover was harvested every fall, typically late October or November using a flail chopper with an attached weigh wagon. For the high harvest treatment, stover from all corn rows was harvested at a stalk cutting height of $10 \mathrm{~cm}$ for minimum soil disturbance. The moderate removal treatment had $50 \%$ of the corn rows harvested, where harvested rows within each plot were alternated every other year. The 50 or $100 \%$ of rows harvested corresponded to $\sim 70$ and $\sim 35 \%$ of standing non-grain biomass removed, respectively (Schmer et al., 2014).

\section{Soil Sampling and Preparation}

Soils were sampled at all sites in the fall of 2014 using a 4.1 $\mathrm{cm}$ diam. (for the Nebraska sites) and 5-cm diam. (Colorado) Giddings probe for a single core from each field replicate. Intact cores were separated into three depths (0-7.5, 7.5-15, and 15$30 \mathrm{~cm}$ ), sieved through $8 \mathrm{~mm}$ mesh, and all large roots and nonsoil materials removed. Soil bulk density was determined for each sampling depth using the core method. Soil bulk density was used to calculate SOC and total soil nitrogen (TSN) mass. A field-moist 20-g subsample was hand-picked to remove plant material, frozen at $-22^{\circ} \mathrm{C}$ for microbial analysis, and the rest of the sample was air-dried for soil characterization and aggregate analyses. Frozen soil subsamples for PLFA analysis were then freeze-dried (Labconco FreeZone 77530, Kansas City, MO) and stored at room temperature until lipid extraction.

\section{Soil Carbon and Nitrogen Analyses}

Air-dried 8-mm sieved soils were finely ground and analyzed for soil total C, SOC, TSN, and $\delta^{13} \mathrm{C}$ of SOC using a Europa Scientific carbon nitrogen analyzer with a Solid/Liquid Preparation Module (Dumas combustion sample preparation system) coupled to a Europa 20-20 stable isotope analyzer continuous flow isotope ratio mass spectrometer (Europa Scientific Ltd., Crewe, England). Carbonates were removed before stable isotope analysis using a modified acid fumigation method (Harris et al., 2001). Briefly, $15 \mathrm{mg}$ soil samples were weighed into open silver capsules, moistened with $30 \mu \mathrm{L} \mathrm{DI} \mathrm{H}_{2} \mathrm{O}$ to approximately field capacity, then fumigated for $8 \mathrm{~h}$ in a concen- 
trated $\mathrm{HCl}$ vacuum atmosphere. Fumigated samples were then removed from vacuum, air dried in the fume hood overnight to remove $\mathrm{HCl}$ fumes, then oven dried at $55^{\circ} \mathrm{C}$ for $12 \mathrm{~h}$. Silver capsules were folded closed and wrapped in tin capsules before analyses. All analyses are expressed as oven dry weight $\left(55^{\circ} \mathrm{C}\right)$.

\section{Soil Aggregation}

Air-dried 8-mm sieved soils were sieved with a modified Yoder apparatus into four smaller fractions: 2 to $8 \mathrm{~mm}, 2 \mathrm{~mm}$ to $250 \mu \mathrm{m}$, 250 to $53 \mu \mathrm{m}$, and $<53 \mu \mathrm{m}$ (Kemper and Rosenau 1986, Follett et al., 2009). Briefly, a 50-g subsample was placed on a 2-mm sieve in $1 \mathrm{~cm}$ water and allowed to slake for $5 \mathrm{~min}$. Stacked sieves were gently sieved in a column of water for $10 \mathrm{~min}$. Fractions were transferred to pans and dried at $50^{\circ} \mathrm{C}$. Ten milliliters of flocculent $(0.5$ $\mathrm{M} \mathrm{CaCl}+0.5 \mathrm{MgCl}$ ) was added to the $<53 \mu \mathrm{m}$ fraction to hasten silt and clay settling after which the supernatant was discarded. Aggregate fractions $>53 \mu \mathrm{m}$ were summed and expressed as gram aggregates per kilogram soil. Profile $(0-30 \mathrm{~cm})$ aggregation was expressed by a weighted average of depth increments.

\section{Phospholipid Fatty Acid Extraction and Identification}

Freeze-dried soil subsamples were analyzed for PLFAs (Ward Laboratories, Inc.; Kearney, NE). Methods for extraction were adapted and modified from Clapperton et al. (2005) and described in detail in Stewart et al. (2018). Briefly, $2 \mathrm{~g}$ soil samples were extracted for phospholipids, which were then converted fatty acid methyl esters (FAMEs) for analysis by gas chromatography (GC; Agilent 7890A). Peaks were identified as specific PLFAs based on comparison of retention times to known standards with an external standard. Soil microbial biomass was estimated as the total abundance of known PLFA biomarkers (see below), and reported as $\mu \mathrm{g}$ PLFA-C $\mathrm{g}^{-1}$ dry soil. Profile microbial biomass was estimated as a depth-weighted average for 0 to $30 \mathrm{~cm}$.

Known PLFAs were classified into general bacteria, grampositive bacteria, gram-negative bacteria, actinomycetes, arbuscular mycorrhizal fungi (AMF), saprotrophic fungi, and universal biomarkers. The 3-OH 12:0, 14:0, 15:0, 3-OH 14:0, 17:0, and 18:0 are used as general bacterial indicators (Frostegard et al., 2011; Zelles, 1999). The i-15:0, a-15:0, i-16:0, i-17:0, and a-17:0 are classified as Gram-positive bacteria while 2-OH 10:0,

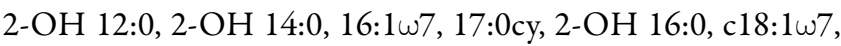
and 19:0cy are classified as Gram-negative bacteria (Zelles, 1999). The 10ME16:0, 10ME17:0 and 10ME18:0 are classified as actinomycete biomarkers. The 16:1 $\omega 5,20: 4 \omega 6,20: 4 \mathrm{w} 3$, and 20:1 are biomarkers for arbuscular mycorrhizal fungi (AMF)

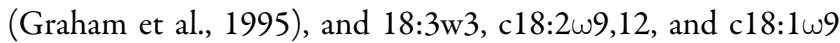
are biomarkers for saprotrophic fungi (Zelles, 1999). The 16:0 fatty acid is classified as a universal PLFA (Zelles, 1999). Soil microbial community structure was evaluated by individual PLFA biomarkers or by functional groups defined above and reported as relative abundance (mol\%).

\section{Data Analysis and Statistics}

We used a general linear mixed effects model to analyze fixed main effects of site, residue management, and soil depth and their interactions, with replicate as a random effect (SAS v. 9.4) (SAS Institute, Cary, NC). Response variables were SOC concentration, SOC stocks, SOC $\delta^{13} \mathrm{C}$, bulk density, microbial biomass, fungal/ bacterial ratio, gram-positive/gram-negative ratio, and water stable aggregation $\left(\mathrm{g} \mathrm{kg}^{-1}\right.$ soil). Profile SOC stocks $\left(\mathrm{MgC} \mathrm{ha}^{-1}\right)$ and weight average microbial biomass (ng PLFA-C g ${ }^{-1}$ soil) were run with a general linear mixed effects model with main effects of site and residue management with block as a random effect. Where necessary, data were log transformed to meet assumptions of normality and equal variance. Significant treatment effects were evaluated with multiple comparisons, with $P$ values noted in the text after Bonferroni adjustment. Differences are considered significant when $P<0.05$, unless otherwise noted.

Microbial community structure was analyzed by calculating the relative abundance of PLFA biomarkers (mol\%) by microbial functional group followed by distance-based redundancy analysis (dbRDA) using Bray-Curtis distances, resulting eigenvalues were used to evaluate whether microbial biomarkers grouped by experimental treatment. Permutation-based ANOVA was performed on all dbRDA models to determine main effects significance among group differences. Ellipsoids represent standard error around the multivariate-group centroids.

\section{RESULTS}

\section{Soil Organic Carbon Concentration}

Soil organic C concentration increased across sites from West to East (Colorado to eastern Nebraska) from 10.5, 16.2, to $18.7 \mathrm{~g} \mathrm{C} \mathrm{kg}^{-1}$ soil averaged across depths and residue treatments (data not shown, $\left.P_{\text {Site }}<0.0001\right)$. Residue harvest decreased SOC by $15 \%$ in the 0 - to $7.5-\mathrm{cm}$ depth only $\left(P_{\text {Depth } \times \text { Residue }}=0.007\right)$. Averaged across sites and residue treatments, $\mathrm{SOC}$ concentration decreased with depth, from $19.3 \mathrm{~g} \mathrm{C} \mathrm{kg}^{-1}$ to 13.8 to $12.3 \mathrm{~g} \mathrm{C} \mathrm{kg}^{-1}$ in the 0 - to 7.5-, 7.5- to 15-, and 15- to $30-\mathrm{cm}$ depths, respectively $\left(P_{\text {Depth }}<0.0001\right)$. There were no three-way interactions.

\section{Bulk Density}

Sites and soil depths differed in bulk density, but there was no residue effect (data not shown, Table 2). Bulk density was $1.13 \mathrm{~g} \mathrm{~cm}^{-3}$ at ENREC, to 1.25 and $1.49 \mathrm{~g} \mathrm{~cm}^{-3}$ at SCAL and ARDEC, respectively $\left(P_{\text {Site }}<0.0001\right)$. Bulk density increased with depth, from $1.16 \mathrm{~g} \mathrm{~cm}^{-3}$ in the 0 - to $7.5-\mathrm{cm}$ depth to 1.36 and $1.35 \mathrm{~g} \mathrm{~cm}^{-3}$ for the 7.5 - to 15 - and 15 - to $30-\mathrm{cm}$ depths, respectively $\left(P_{\text {Depth }}<0.0001\right)$.

\section{Soil Organic Carbon Stocks}

Soil C stock values paralleled site and depth patterns for SOC concentrations, increasing from West to East and decreasing with soil depth, with a significant site $\times$ depth interaction driven by the high $C$ mass of the 7.5 - to $15-\mathrm{cm}$ depth at ENREC $\left(P_{\text {Site } \times \text { Depth }}<0.0001\right)$ (Fig. 1a; Tables 2, 3). Stover harvest decreased SOC stocks relative to residue retained $\left(P_{\text {Residue }}=\right.$ 

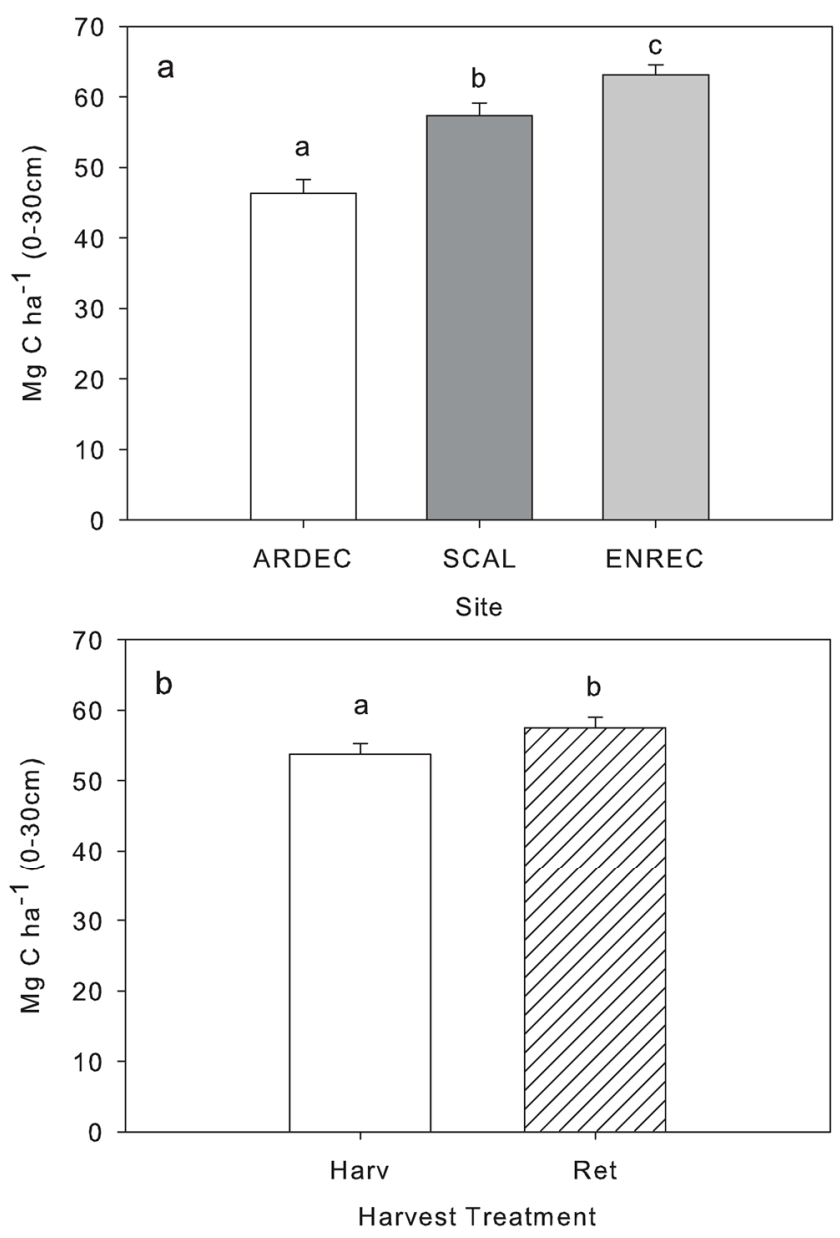

Fig. 1. (a) Soil organic $\mathrm{C}$ stocks $\left(\mathrm{Mg} \mathrm{C} \mathrm{ha}^{-1}\right)$ for the three sites, Colorado (ARDEC), central Nebraska (SCAL), and eastern Nebraska (ENREC) (b) for the 0 - to $30-\mathrm{cm}$ depth with corn stover either harvested (Harv) or retained (Ret). Error bars represent standard error of the mean.

0.016) (Fig. 1b; Tables 2, 3). Because there were no residue treatment interactions, SOC stocks were summed over all depths and reassessed for site, residue, and their interaction effects. For the 0 to 30-cm depth, SOC stocks increased from West to East, from 46.4, 57.4, to 63.1 Mg C ha- ${ }^{-1}$ for ARDEC, SCAL, and ENREC, respectively $\left(P_{\text {Site }}<0.0001\right)$ (Fig. 1a, Table 3$)$. Residue harvest reduced soil $\mathrm{C}$ mass by $6 \%$ relative to residue retained soils, or 57.5 to $53.8 \mathrm{Mg} \mathrm{C} \mathrm{ha}^{-1}\left(P_{\text {Residue }}=0.041\right)$ (Fig. 1b, Table 3). There was no site $\times$ residue interaction.
Table 3. Soil organic $\mathrm{C}$ mass $\left(\mathrm{Mg} \mathrm{C} \mathrm{ha}^{-1}\right)$ for three sites located in Colorado (ARDEC), central Nebraska (SCAL), and eastern Nebraska (ENREC) for the three soil depths with stover either harvested (Harv) or retained (Ret). Lowercase letters indicate significant differences between sites and uppercase letters differences between residue treatments.

\begin{tabular}{lcccc} 
Site & Depth & Harv & Ret & Residue mean \\
\hline \multirow{4}{*}{ ARDEC } & $\mathrm{cm}$ & & $\mathrm{Mg} \mathrm{C} \mathrm{ha}$ & \\
& $0-7.5$ & 14.2 & 16.9 & 15.6 \\
& $7.5-15$ & 11.4 & 11.4 & 11.4 \\
& $15-30$ & 19.1 & 19.4 & 19.3 \\
& $0-30$ mean & 44.8 & 47.9 & $46.4 \mathrm{a}$ \\
SCAL & $0-7.5$ & 17.4 & 18.1 & 17.8 \\
& $7.5-15$ & 14.9 & 15.8 & 15.3 \\
& $15-30$ & 23.2 & 25.3 & 24.3 \\
& $0-30$ mean & 55.5 & 59.2 & $57.4 \mathrm{~b}$ \\
ENREC & $0-7.5$ & 14.6 & 18.2 & 16.4 \\
& $7.5-15$ & 15.5 & 16.4 & 16.0 \\
& $15-30$ & 30.8 & 30.7 & 30.8 \\
& $0-30$ mean & 60.9 & 65.3 & $63.1 \mathrm{c}$ \\
Site mean & $0-30$ mean & $53.8 \mathrm{~A}$ & $57.5 \mathrm{~B}$ & \\
\hline
\end{tabular}

\section{$\delta^{13} \mathrm{C}$ of Soil Organic Carbon}

Soil organic $\delta^{13} \mathrm{C}$ generally increased from West to East, and residue harvest further decreased $\delta^{13} \mathrm{C}$ at ARDEC but not at SCAL or ENREC $\left(P_{\text {Site } \times \text { Residue }}=0.044\right)($ Tables 2,4$)$. This residue effect was limited to near-surface soils $(0-7.5 \mathrm{~cm})$, but not the deeper soil depths $\left(P_{\text {Depth } \times \text { Residue }}=0.019\right)$ (Tables 2,4$)$. Changes in SOC $\delta^{13} \mathrm{C}$ with soil depth was site-specific $\left(P_{\text {Site } \times \text { Depth }}<\right.$ 0.0001), where SOC $\delta^{13} \mathrm{C}$ increased with depth at ENREC and SCAL, but decreased with depth at ARDEC (Tables 2, 4).

\section{Aggregation}

There was no main or interaction effects of depth on soil aggregation (Table 2), so aggregate values were pooled as means weighted by depth increment for the full 0 - to 30-cm soil depth, then re-analyzed for main and interaction effects of site and residue treatment. Aggregation in the top $30 \mathrm{~cm}$ of soil was site-specific, with SCAL > ARDEC > ENREC. Residue harvest decreased aggregation 12\% averaged over sites from 609 to $537 \mathrm{~g} \mathrm{~kg}^{-1}(P=0.005$, Fig. 2b) driven primarily by decreased

Table 2. $P$ values for main and interaction effects of variables for three sites located in Colorado (ARDEC) central Nebraska (SCAL), and eastern Nebraska (ENREC) for the three soil depths with stover either harvested (Harv) or retained (Ret).

\begin{tabular}{|c|c|c|c|c|c|c|c|c|}
\hline Effect & Num df & Den $\mathrm{df}$ & SOCt & Bulk density & SOC stocks & $\operatorname{SOC} \delta^{13} \mathrm{C}$ & Aggregation & PLFA \\
\hline & & & $\mathrm{g} \mathrm{kg}^{-1}$ & $\mathrm{~g} \mathrm{~cm}^{-3}$ & $\mathrm{~kg} \mathrm{ha}^{-1}$ & $\%$ & $\%$ & ng PLFA-C g-1 \\
\hline Site & 2 & 55 & 0.000 & 0.000 & 0.000 & 0.000 & 0.001 & 0.126 \\
\hline Residue & 1 & 55 & 0.039 & 0.383 & 0.016 & 0.228 & 0.019 & 0.198 \\
\hline Depth & 2 & 55 & 0.000 & 0.000 & 0.000 & 0.000 & 0.173 & 0.000 \\
\hline Site $\times$ Residue & 2 & 55 & 0.291 & 0.227 & 0.946 & 0.044 & 0.064 & 0.244 \\
\hline Site $\times$ Depth & 4 & 55 & 0.164 & 0.907 & 0.000 & 0.000 & 0.894 & 0.086 \\
\hline Depth $\times$ Residue & 2 & 55 & 0.007 & 0.627 & 0.262 & 0.019 & 0.575 & 0.737 \\
\hline Site $\times$ Depth $\times$ Residue & 4 & 55 & 0.968 & 0.282 & 0.422 & 0.851 & 0.509 & 0.548 \\
\hline
\end{tabular}

+ SOC, soil organic carbon; PLFA, phospholipid fatty acids. 
aggregation at ARDEC (28\%) but not at ENREC or SCAL $\left(P_{\text {Site } \times \text { Residue }}=0.011\right)$ (Fig. 2$)$.

\section{Soil Microbial Biomass}

Soil microbial biomass (PLFA-C) was not affected by main or interaction effects of site and residue but decreased with depth, from 2369.4 to 1051.3 to $790 \mathrm{ng}$ PLFA-C g ${ }^{-1}$ soil in the 0 - to 7.5-, 7.5- to 15 -, and 15 - to 30 -cm depths, respectively $\left(P_{\text {Depth }}\right.$ $<0.0001$ ) (Fig. 3). There were no significant interactions of site, residue and depth. Residue harvest tended to decrease microbial biomass in the 0 to 7.5 depth and through the 0 - to 30-cm depth (i.e., mean weighted by depth increment) $\left(P_{\text {Residue }}=0.119\right)$, but again, there were no significant main or interaction effects of site.

\section{Microbial Community Composition}

Fungal/bacterial ratio was greater and the gram-positive/ gram-negative ratio was lower in Colorado compared to the two Nebraska sites $\left(P_{\text {Site }}<0.0001\right)$ (Table 5$)$. In addition, fungal/ bacterial ratio decreased with depth and gram-positive/gramnegative ratio increased with depth $\left(P_{\text {Depth }}=0.023\right)$ (Table 5). There was no main or interaction residue effects or any other interaction effects.

Permutation-based ANOVA on soil microbial composition based on the relative abundance of functional groups (mol\%) indicated differences between sites $(P<0.001)$ and soil depths $(P<0.001)$, but not residue treatments or any other treatment interactions (Fig. 4). Specifically, the dbRDA of microbial community structure separated sites

Table 4. Soil organic $\delta^{13} \mathrm{C}$ for Colorado (ARDEC), central Nebraska (SCAL), and eastern Nebraska (ENREC) sites by soil depth with stover harvested (Harv) or retained (Ret). Lowercase letters indicate differences between harvest treatments within depths or differences between depths within site. Uppercase letters represent average harvest differences or differences between sites.

\begin{tabular}{|c|c|c|c|c|}
\hline Site & Depth & Harv & Ret & Residue mean \\
\hline & $\mathrm{cm}$ & 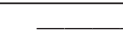 & ${ }^{13} \mathrm{C}$ of $\mathrm{SO}$ & $\%$ \\
\hline \multirow[t]{4}{*}{ ARDEC } & $0-7.5$ & -18.59 & -17.60 & $-18.10 \mathrm{a}$ \\
\hline & $7.5-15$ & -19.24 & -19.31 & $-19.28 b$ \\
\hline & $15-30$ & -19.85 & -19.48 & $-19.67 c$ \\
\hline & 0-30 mean & $-19.23 a$ & $-18.80 b$ & $-19.01 C$ \\
\hline \multirow[t]{4}{*}{ SCAL } & $0-7.5$ & -16.60 & -16.56 & $-16.58 a$ \\
\hline & $7.5-15$ & -15.53 & -15.83 & $-15.68 b$ \\
\hline & $15-30$ & -14.16 & -14.66 & $-14.41 c$ \\
\hline & 0-30 mean & $-15.43 a$ & $-15.68 \mathrm{a}$ & $-15.56 \mathrm{~A}$ \\
\hline \multirow[t]{4}{*}{ ENREC } & $0-7.5$ & -16.94 & -16.27 & $-16.61 \mathrm{a}$ \\
\hline & $7.5-15$ & -16.62 & -16.65 & $-16.64 a b$ \\
\hline & $15-30$ & -15.95 & -15.96 & $-15.96 b$ \\
\hline & 0-30 mean & $-16.51 \mathrm{a}$ & $-16.29 a$ & $-16.40 \mathrm{~B}$ \\
\hline \multirow[t]{3}{*}{ All Sites } & $0-7.5$ mean & $-17.38 b$ & $-16.81 \mathrm{a}$ & \\
\hline & 7.5-15 mean & $-17.13 a$ & $-17.27 a$ & \\
\hline & 15-30 mean & $-16.66 \mathrm{a}$ & $-16.70 a$ & \\
\hline \multicolumn{2}{|c|}{$0-30$ mean } & $-17.06 \mathrm{~A}$ & $-16.93 \mathrm{~A}$ & \\
\hline
\end{tabular}

and explained $19.8 \%$ of variability along Axis 1 and $0.5 \%$ along Axis 2 (Fig. 4). Along Axis 1, ENREC separating along universal, SCAL along actinomycetes, and ARDEC separated toward AMF, fungi and gram-negative bacteria. Microbial community structure also separated by soil depth, which explained $13.3 \%$ of variability along Axis 1 and $0.3 \%$ along Axis 2. Along Axis 1, surface soils $(0-7.5 \mathrm{~cm})$ separat-
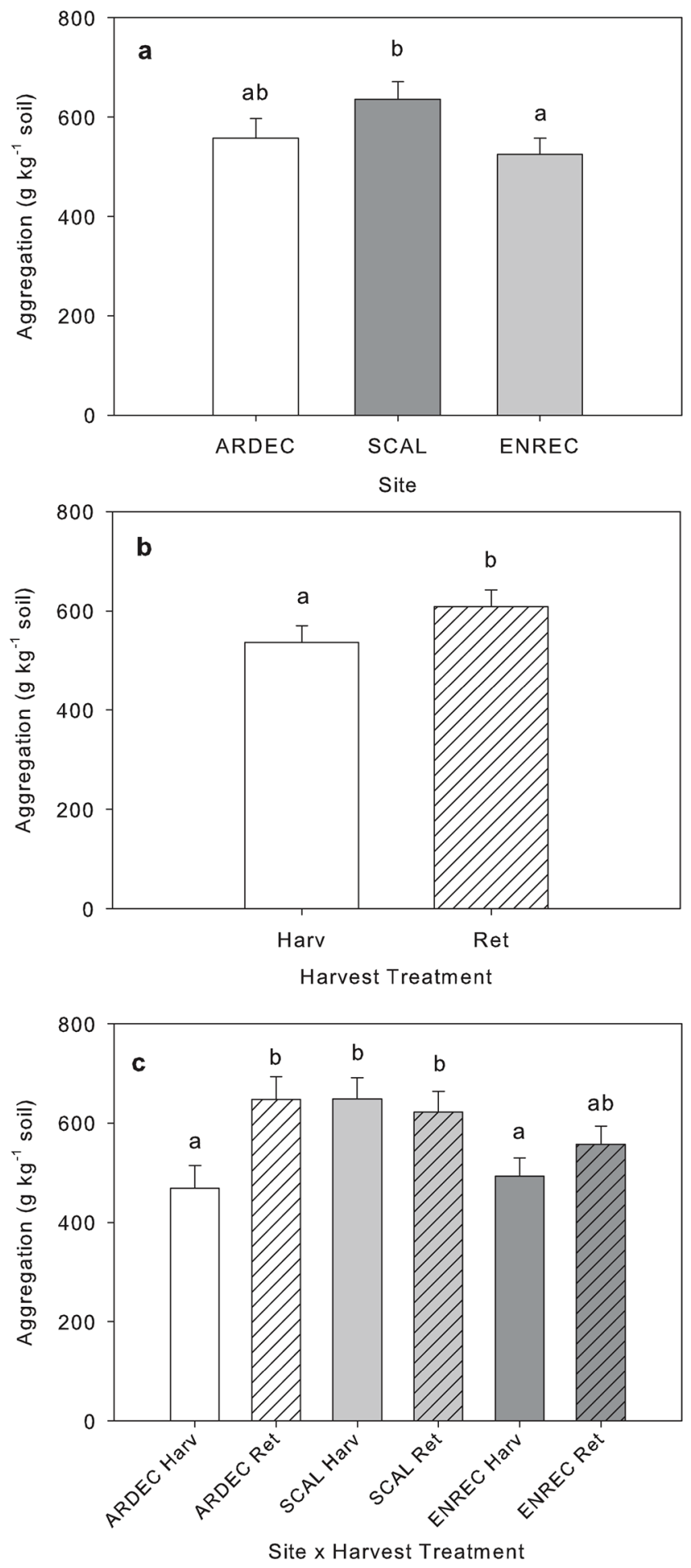

Fig. 2. (a) Soil aggregation ( $\mathrm{g} \mathrm{kg}^{-1}$ soil) for the three sites, Colorado (ARDEC), central Nebraska (SCAL), and eastern Nebraska (ENREC) (b) for the 0 - to $30-\mathrm{cm}$ depth with corn stover either harvested (Harv) or retained (Ret) and (c) their interaction. Error bars represent standard error of the mean. 
ed toward gram-negative bacteria, fungi and AMF, and the deepest depth $(15-30 \mathrm{~cm})$ separated toward gram-positive bacteria and universal.

\section{DISCUSSION}

Despite long-term NT management (4-13 yr), stover harvest at these three irrigated continuous corn sites resulted in lower SOC stocks and aggregation compared to residue retained treatments. This suggests that NT management alone is inadequate to reduce erosion potential and maintain soil function in mesic and semiarid irrigated corn production systems, even though these effects are not always observed in the short term. Residue harvest did not decrease SMB or change soil microbial community structure, suggesting that NT and the high plant productivity in these irrigated systems buffered microbial community properties from residue harvest impacts. In short, high crop productivity with irrigation appears to stimulate activity levels of the existing soil microbial community, leading to SOC losses as a result of enhanced microbial decomposition and aggregate turnover in these NT continuous corn systems.

\section{Soil Organic Carbon and $\delta^{13} \mathrm{C}$ of Soil Organic Carbon}

In the top $30 \mathrm{~cm}$ of soils, residue removal resulted in $6 \%$ lower SOC stocks despite NT management practices. Our findings are consistent with low SOC storage potentials reported in

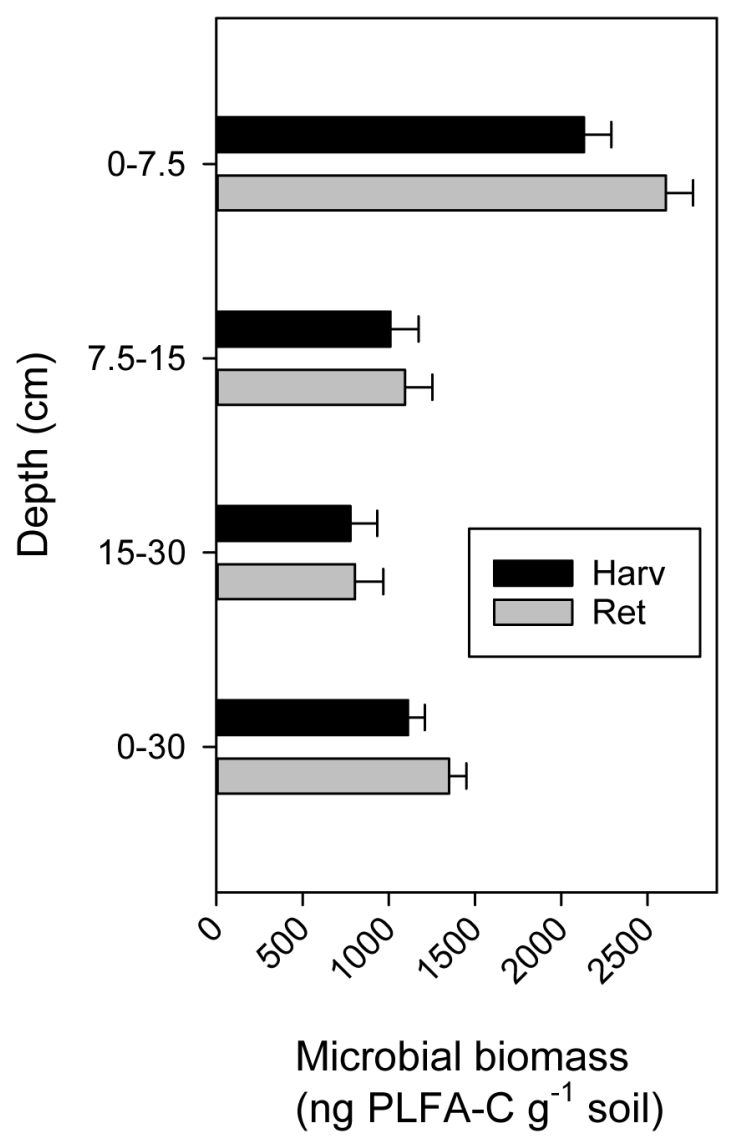

Fig. 3. Soil microbial biomass (ng PLFA-C $\mathrm{g}^{-1}$ soil) averaged over the three sites, Colorado (ARDEC), central Nebraska (SCAL), and eastern Nebraska (ENREC) for the three soil depths and weight averaged for the 0 to $30 \mathrm{~cm}$ with residue either harvested (Harv) or retained (Ret). Errors represent standard error of the mean. intensively-managed irrigated corn systems, where high productivity levels are offset by greater decomposition rates stimulated by higher water and nutrient availabilities (Verma et al., 2005; Follett et al., 2013; Schmer et al., 2014). Furthermore, similar field-based findings have been reported in rainfed systems documenting reduced $\mathrm{C}$ stocks with long-term residue removal compared to stover retained treatments (Anderson-Teixeira et al., 2009; Lehman and Osborne 2016) or no change in soil C stocks compared to an increase with stover retention (Clapp et al., 2000; Halvorson and Stewart, 2015). Studies reporting no change in SOC under NT with residue removal tend to be in soils with high initial soil C (Moebius-Clune et al., 2008; Reicosky et al., 1997) or with short experimental duration with relatively low removal rates (Johnson et al., 2014).

The SOC $\delta^{13} \mathrm{C}$ signature indicated less storage of new $\mathrm{C}$ when residue was removed at the most arid site in Colorado (ARDEC). Other studies that have used $\delta^{13} \mathrm{C}$ find lower incorporation of new corn-derived C with residue removal. For example, Clapp et al. (2000) reported that new $\mathrm{C}$ accounted for $5 \%$ of total SOC with residue removal compared to $15 \%$ without residue removal under NT on a Mollisol in Minnesota. At ARDEC, lower C storage of new C suggests rapid $\mathrm{C}$ cycling from enhanced decomposition (Stewart et al., 2018). No changes in SOC $\delta^{13} \mathrm{C}$ signature at the Nebraska sites indicated that SOC losses may be due to irrigation-enhanced decomposition or erosion of existing soil $\mathrm{C}$ rather than reduction in new $\mathrm{C}$ inputs with residue removal. For all three sites, residue removal reduced C inputs from stover overall. Further, removal of the protective physical barrier of residue likely stimulated residue or SOC decomposition rates by exposing soils to greater evaporation rates and fluctuations in surface temperature (Steiner, 1994; Wilhelm et al., 2004). Stover removal also may have changed plant rooting patterns. Although NT can promote surface rooting, residue removal treatments in rainfed systems resulted in fewer, deeper roots, presumably in response to surface drying (Stewart et al., 2016).

\section{Residue Removal Impacts on Microbial Biomass and Microbial Community Structure}

Despite decreased SOC with residue removal, there was little effect of residue removal on SMB and its community composition. Other no-till continuous corn studies have also

Table 5. Fungal/bacterial ratios (F/B) and gram-positive/ gram-negative ratios (Gpos/Gneg) for three sites located in Colorado (ARDEC), central Nebraska (SCAL), and eastern Nebraska (ENREC) for the three soil depths.

\begin{tabular}{lcc} 
Effect & F/B & Gpos/Gneg \\
\hline ARDEC & $0.179 \mathrm{a}$ & $0.87 \mathrm{a}$ \\
ENREC & $0.078 \mathrm{~b}$ & $1.79 \mathrm{~b}$ \\
$\mathrm{SCAL}$ & $0.091 \mathrm{~b}$ & $1.85 \mathrm{~b}$ \\
$0-7.5 \mathrm{~cm}$ & $0.144 \mathrm{a}$ & $1.03 \mathrm{a}$ \\
$7.5-15 \mathrm{~cm}$ & $0.106 \mathrm{ab}$ & $1.43 \mathrm{~b}$ \\
$15-30 \mathrm{~cm}$ & $0.098 \mathrm{~b}$ & $2.05 \mathrm{c}$ \\
& $P$ & $P$ \\
Site & $<0.0001$ & $<0.0001$ \\
Residue & 0.444 & 0.505 \\
Depth & 0.023 & $<0.0001$ \\
\hline
\end{tabular}




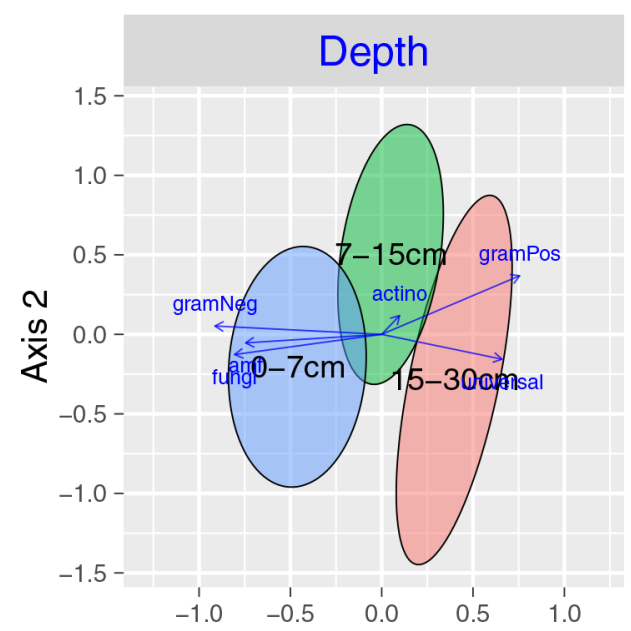

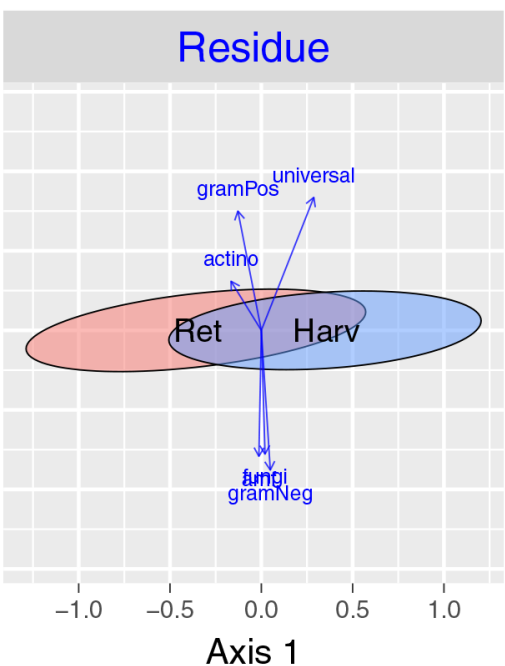

Axis 1

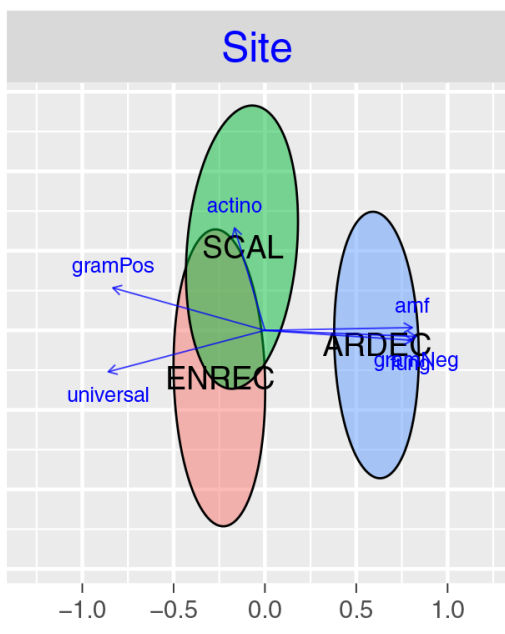

Fig. 4. Soil microbial community composition (mol\%) for the three sites, Colorado (ARDEC), central Nebraska (SCAL), and eastern Nebraska (ENREC), three soil depths and residue treatments (harvested or retained). Ellipses represent standard error from the distance-based redundancy analysis (dbRDA).

reported no effect of residue removal on SMB (Ahlschwede, 2013; Johnson et al., 2013; Spedding et al., 2004). Although we expected relatively more fungal biomass with residue retention, fungal biomass may have been well equilibrated to the long-term NT practices, resulting in a comparatively small effect of residue removal. A previous study at the irrigated Colorado site (ARDEC) also found that residue removal did not alter the relative abundance of PLFAs, fungal/bacteria ratios, or grampositive/gram-negative ratios (Stewart et al., 2018). Many other rainfed long-term NT studies have similar results. Lehman et al. (2014) found only one of four NT rainfed corn or mixed rotation sites to have greater fungal/bacteria ratios under residue retained compared to harvested ( $98 \%$ aboveground biomass) after 9 to $10 \mathrm{yr}$ of treatment. Two other sites (Nebraska, $10 \mathrm{yr}$ and Minnesota, $8 \mathrm{yr}$ ) showed no difference with residue harvest. One site had greater fungal abundance after only $2 \mathrm{yr}$ of removal. Johnson et al. (2013) found FAME profiles to differ under CT with residue removal, but not under NT.

Both irrigation and NT management practices potentially dampen the two largest drivers of microbial response: $\mathrm{C}$ input and microclimatic effects. Generally, residue removal limits $\mathrm{C}$ inputs by reducing overall aboveground $\mathrm{C}$, decreasing surface rooting, and stimulating decomposition through increased soil surface drying, destabilization of surface temperatures, and decreased water retention (Steiner, 1994; Wilhelm et al., 2004). Irrigation, however, can moderate soil microclimatic variability and increase $\mathrm{C}$ input and nutrient availability for microbial use by boosting crop productivity and promoting the movement of dissolved organic $\mathrm{C}$ and nutrients between previously isolated soil pores. Similarly, NT reduces overall soil disturbance and can provide greater belowground $\mathrm{C}$ inputs and higher soil connectivity by supporting more surface rooting (Stewart et al., 2016). Thus, the lack of residue removal effect on $\mathrm{SMB}$ and soil microbial community structure may be attributed to the ameliorating effects of irrigation and NT in these long-term continuous corn systems.

\section{Aggregation as a Sensitive Indicator for Residue Removal}

Soil aggregation was an indicator of residue removal, but only for two of three study sites (ARDEC, ENREC). In rainfed continuous corn production systems, residue removal can decrease surface aggregation (Blanco-Canqui and Lal, 2007; Jin et al., 2015) from decreased aboveground and root-C return (Stewart et al., 2016). Soil aggregates form around organic $C$ sources like particulate organic matter, root exudates, and microbial exudates (Six et al., 2004). The stability of these aggregates is expected to decrease with residue removal by greater exposure to disruption by dry-wet and freeze-thaw cycles (Wienhold et al., 2013). Irrigation could exacerbate residue removal effects on aggregation due to more frequent dry-wet cycles and increased microbial decomposition (discussed previously), as noted for two of three sites in this study. Gillabel et al. (2007), however, found no difference in microaggregation between irrigated and dryland sites, despite two and a half times greater aboveground productivity under irrigation. We also found no aggregate response to residue removal at the SCAL site. The lack of aggregate response may be due to high $\mathrm{C}$ inputs, high initial SOC concentration, and/or high mineral content, all of which confer soils with greater ability to absorb reductions in $\mathrm{C}$ input without altering soil structure (Blanco-Canqui and Lal, 2007; Stewart et al., 2014). The use of NT could further buffer soils from residue removal impacts on soil aggregation, but several years may be required before the benefits of NT appear.

\section{CONCLUSIONS}

Residue removal in irrigated NT continuous corn systems appears to have two contrasting mechanisms that both exacerbate $\mathrm{C}$ losses and while buffering the microbial community. Enhanced crop productivity and root exudation increase $\mathrm{C}$ availability to the microbial community, buffering residue removal effects. However, the addition of irrigation water accelerates microbial decomposition and aggregate turnover, leading to a depletion of existing SOC stocks compared to residue retained. While soil microbial biomass 
and community structure did not change in these NT systems, $\mathrm{NT}$ alone is inadequate for maintaining both soil C stocks and soil aggregation with residue removal in these irrigated systems.

\section{ACKNOWLEDGMENTS}

We thank B. Floyd, R. D’Adamo, A. Brandt, L. Pruessner, E. Grogan, S. Siragusa, and many student assistants for their assistance in collecting, processing, and analyzing the soil and plant samples. We acknowledge the Colorado State University ARDEC, University of Nebraska SCAL and ENRIC Staff for help with plot maintenance. This publication is based on work supported by the Agricultural Research Service under the ARS GRACEnet Project. Trade names and company names are included for the benefit of the reader and do not imply any endorsement or preferential treatment of the product by the authors or the USDA-ARS.

\section{REFERENCES}

Ahlschwede, C.M. 2013. Microbial ecology, nitrogen, and nitrous oxide trends in marginal soils used for cellulosic biofuel production in eastern Nebraska. Masters. Univ. of Nebraska, Lincoln.

Anderson-Teixeira, K.J., S.C. Davis, M.D. Masters, and E.H. Delucia. 2009. Changes in soil organic carbon under biofuel crops. Glob. Change Biol. Bioenergy 1:75-96. doi:10.1111/j.1757-1707.2008.01001.x

Blanco-Canqui, H., R.B. Ferguson, V.L. Jin, M.R. Schmer, B.J. Wienhold, and J. Tatarko. 2014. Can cover crop and manure maintain soil properties after stover removal from irrigated no-till corn? Soil Sci. Soc. Am. J. 78:1368 1377. doi: 10.2136/sssaj2013.12.0550

Blanco-Canqui, H., and R. Lal. 2007. Soil and crop response to harvesting corn residues for biofuel production. Geoderma 141:355-362. doi:10.1016/j. geoderma.2007.06.012

Clapp, C.E., R.R. Allmaras, M.F. Layese, D.R. Linden, and R.H. Dowdy. 2000. Soil organic carbon and 13C abundance as related to tillage, crop residue, and nitrogen fertilization under continuous corn management in Minnesota. Soil Tillage Res. 55:127-142. doi:10.1016/S0167-1987(00)00110-0

Clapperton, M.J., M.J. Lacey, K. Hanson, and C. Hamel. 2005. Analysis of phospholipid and neutral lipid fatty acids extracted from soil. Semiarid Prairie Agric. Res. Centre (SPARC), Swift Current, SK-Agric. Agri-Food Canada (AAFC), Ottawa, ON. p. 1-2.

Cotrufo, M.F., J.L. Soong, A.J. Horton, E.E. Campbell, M.L. Haddix, D.H. Wall, and W.J. Parton. 2015. Formation of soil organic matter via biochemical and physical pathways of litter mass loss. Nat. Geosci. 8:776-779. doi:10.1038/ngeo2520

Denef, K., C.E. Stewart, J. Brenner, and K. Paustian. 2008. Does long-term centerpivot irrigation increase soil carbon stocks in semi-arid agro-ecosystems? Geoderma 145:121-129. doi:10.1016/j.geoderma.2008.03.002

Follett, R.F., C.P. Jantalia, and A.D. Halvorson. 2013. Soil carbon dynamics for irrigated corn under two tillage systems. Soil Sci. Soc. Am. J. 77:951-963. doi:10.2136/sssaj2012.0413

Follett, R.F., G.E. Varvel, J.M. Kimble, and K.P. Vogel. 2009. No-till corn after bromegrass: Effect on soil carbon and soil aggregates. Agron. J. 101:261268. doi:10.2134/agronj2008.0107

Frostegard, A., A. Tunlid, and E. Baath. 2011. Use and misuse of PLFA measurements in soils. Soil Biol. \& Biochem. 43:1621-1625. doi:10.1016/j.soilbio.2010.11.021

Gillabel, J., K. Denef, J. Brenner, R. Merckx, and K. Paustian. 2007. Carbon sequestration and soil aggregation in center-pivot irrigated and dryland cultivated farming systems. Soil Sci. Soc. Am. J. 71:1020-1028. doi:10.2136/sssaj2006.0215

Graham, J.H., N.C. Hodge, and J.B. Morton. 1995. Fatty acid methyl ester profiles for characterization of glomalean fungi and their endomycorrhizae. Appl. Environ. Microbiol. 61:58-64.

Halvorson, A.D., and C.E. Stewart. 2015. Stover removal affects no-till irrigated corn yields, soil carbon, and nitrogen. Agron. J. 107:1504-1512. doi:10.2134/agronj15.0074

Harris, D., W.R. Horwáth, and C. van Kessel. 2001. Acid fumigation of soils to remove carbonates prior to total organic carbon or CARBON-13 isotopic analysis. Soil Sci. Soc. Am. J. 65:1853-1856. doi:10.2136/sssaj2001.1853

Hooker, B.A., T.F. Morris, R. Peters, and Z.G. Cardon. 2005. Long-term effects of tillage and corn stalk return on soil carbon dynamics. Soil Sci. Soc. Am.
J. 69:188-196. doi:10.2136/sssaj2005.0188

Jin, V.L., M.R. Schmer, C.E. Stewart, A.J. Sindelar, G.E. Varvel, and B.J. Wienhold. 2017. Long-term no-till and stover retention each decrease the global warming potential of irrigated continuous corn. Global Change Biol. 23:2848-2862. doi:10.1111/gcb.13637

Jin, V.L., M.R. Schmer, B.J. Wienhold, C.E. Stewart, G.E. Varvel, A.J. Sindelar et al. 2015. Twelve years of stover removal increases soil erosion potential without impacting yield. Soil Sci. Soc. Am. J. 79:1169-1178. doi:10.2136/ sssaj2015.02.0053

Johnson, J., V. Acosta-Martinez, C. Cambardella, and N. Barbour. 2013. Crop and soil responses to using corn stover as a bioenergy feedstock: Observations from the northern US Corn Belt. Agriculture 3:72-89. doi:10.3390/agriculture 3010072

Johnson, J.M.F., R.R. Allmaras, and D.C. Reicosky. 2006. Estimating source carbon from crop residues, roots and rhizodeposits using the national grainyield database. Agron. J. 98:622-636. doi:10.2134/agronj2005.0179

Johnson, J.M.F., J.M. Novak, G.E. Varvel, D.E. Stott, S.L. Osborne, D.L. Karlen et al. 2014. Crop residue mass needed to maintain soil organic carbon levels: Can it be determined? BioEnergy Res. 7:481-490. doi:10.1007/ s12155-013-9402-8

Kemper, W.D., and R.C. Rosenau. 1986. Aggregate stability and size distribution. In: A. Klute, editor, Methods of soil analysis. Part 1. Physical and mineralogical methods. SSSA Book Ser. 5.1. SSSA and ASA, Madison, WI. p. 425-442.

Lal, R., J.M. Kimble, R.F. Follett, and C.V. Cole. 1998. The potential of U.S. cropland to sequester carbon and mitigate the greenhouse effect. Ann Arbor Press, Chelsea, MI.

Lehman, R.M., T. Ducey, V. Jin, V. Acosta-Martinez, C. Ahlschwede, E. Jeske et al. 2014. Soil microbial community response to corn stover harvesting under rain-fed, no-till conditions at multiple US locations. BioEnergy Res. 7:540-550. doi:10.1007/s12155-014-9417-9

Lehman, R.M., and S.L. Osborne. 2016. Soil greenhouse gas emissions and carbon dynamics of a no-till, corn-based cellulosic ethanol production system. BioEnergy Res. 9:1101-1108. doi:10.1007/s12155-016-9754-y

Mann, L., V. Tolbert, and J. Cushman. 2002. Potential environmental effects of corn (Zea mays L.) stover removal with emphasis on soil organic matter and erosion. Agric. Ecosyst. Environ. 89:149-166. doi:10.1016/S01678809(01)00166-9

Moebius-Clune, B.N., H.M. van Es, O.J. Idowu, R.R. Schindelbeck, D.J. Moebius-Clune, D.W. Wolfe et al. 2008. Long-term effects of harvesting maize stover and tillage on soil quality. Soil Sci. Soc. Am. J. 72:960-969. doi:10.2136/sssaj2007.0248

Osborne, S., J.F. Johnson, V. Jin, A. Hammerbeck, G. Varvel, and T. Schumacher. 2014. The impact of corn residue removal on soil aggregates and particulate organic matter. BioEnergy Res. 7:559-567. doi:10.1007/s12155-014-9413-0

Qin, Z., J.B. Dunn, H. Kwon, S. Mueller, and M.M. Wander. 2016. Soil carbon sequestration and land use change associated with biofuel production: Empirical evidence. Glob. Change Biol. Bioenergy 8:66-80. doi:10.1111/ gcbb. 12237

Qin, R., P. Stamp, and W. Richner. 2006. Impact of tillage on maize rooting in a Cambisol and Luvisol in Switzerland. Soil Tillage Res. 85:50-61. doi:10.1016/j.still.2004.12.003

Reicosky, D.C., D.K. Cassel, R.L. Blevins, W.R. Gill, and G.C. Naderman. 1997. Conservation tillage in the southeast. J. Soil Water Conserv. 32:13-19.

Schmer, M.R., V.L. Jin, B.J. Wienhold, G.E. Varvel, and R.F. Follett. 2014. Tillage and residue management effects on soil carbon and nitrogen under irrigated continuous corn. Soil Sci. Soc. Am. J. 78:1987-1996. doi:10.2136/sssaj2014.04.0166

Sindelar, A.J., J.A. Coulter, J.A. Lamb, and J.A. Vetsch. 2013. Agronomic responses of continuous corn to stover, tillage, and nitrogen management. Agron. J. 105:1498-1506. doi:10.2134/agronj2013.0181

Six, J., H. Bossuyt, S. Degryze, and K. Denef. 2004. A history of research on the link between (micro)aggregates, soil biota, and soil organic matter dynamics. Soil Tillage Res. 79:7-31. doi:10.1016/j.still.2004.03.008

Spedding, T.A., C. Hamel, G.R. Mehuys, and C.A. Madramootoo. 2004. Soil microbial dynamics in maize-growing soil under different tillage and residue management systems. Soil Biol. Biochem. 36:499-512. doi:10.1016/j.soilbio.2003.10.026

Steiner, J.L., editor. 1994. Crop residue effects on water conservation. CRC Press, Boca Raton, FL. 
Stewart, C.E., R.F. Follett, E.G. Pruessner, G.E. Varvel, K.P. Vogel, and R.B. Mitchell. 2014. Nitrogen and harvest effects on soil properties under rainfed switchgrass and no-till corn over 9 years: Implications for soil quality. Glob. Change Biol. Bioenergy 7:288-301. doi:10.1111/gcbb.12142

Stewart, C.E., R.F. Follett, E.G. Pruessner, G.E. Varvel, K.P. Vogel, and R.B. Mitchell. 2016. N fertilizer and harvest impacts on bioenergy crop contributions to SOC. Glob. Change Biol. Bioenergy 8:1201-1211. doi: $10.1111 / \mathrm{gcbb} .12326$

Stewart, C.E., A.D. Halvorson, and J.A. Delgado. 2017. Long-term N fertilization and conservation tillage practices conserve surface but not profile SOC stocks under semi-arid irrigated corn. Soil Tillage Res. 171:918. doi:10.1016/j.still.2017.04.003

Stewart, C.E., D.L. Roosendaal, D.K. Manter, J.A. Delgado, and S. Del Grosso. 2018. Interactions of stover and nitrogen management on soil microbial community and labile carbon under irrigated no-till corn. Soil Sci. Soc Am. J. 82(2):323-331. doi:10.2136/sssaj2017.07.0229
Verma, S.B., A. Dobermann, K.G. Cassman, D.T. Walters, J.M. Knops, T.J. Arkebauer et al. 2005. Annual carbon dioxide exchange in irrigated and rainfed maize-based agroecosystems. Agric. For. Meteorol. 131:77-96. doi:10.1016/j.agrformet.2005.05.003

Wienhold, B.J., G.E. Varvel, J.M.F. Johnson, and W.W. Wilhelm. 2013. Carbon source quality and placement effects on soil organic carbon status. BioEnergy Res. 6:786-796. doi:10.1007/s12155-013-9301-z

Wilhelm, W.W., J.M.F. Johnson, J.L. Hatfield, W.B. Voorhees, and D.R. Linden. 2004. Crop and soil productivity response to corn residue removal. Agron. J. 96:1-17. doi:10.2134/agronj2004.0001

Wilhelm, W.W., J.M.E. Johnson, D.L. Karlen, and D.T. Lightle. 2007. Corn stover to sustain soil organic carbon further constrains Biomass supply. Agron. J. 99:1665-1667. doi:10.2134/agronj2007.0150

Zelles, L. 1999. Fatty acid patterns of phospholipids and lipopolysaccharides in the characterisation of microbial communities in soil: A review. Biol. and Fertility of Soils 29:111-129. doi:10.1007/s003740050533 